\title{
The importance of project management competences: a case study in public administration
}

\author{
Eliane Gonzales Meirelles, Anabela Tereso and Cláudio Santos \\ Production and Systems Department / Centre ALGORITMI \\ University of Minho, Campus de Azurém, 4804-533 Guimarães, Portugal \\ gonzaleseli2011@hotmail.com, anabelatedps.uminho.pt, \\ claudio.santosedps. uminho.pt
}

\begin{abstract}
Public administration is increasingly implementing new management practices borrowed from the private sector with the aim of improving quality service. Public funded projects have specific characteristics, namely regulatory, in resources usage and accountability, that may be related in different ways to existing competence models. However, it is generally understood that project management practices can improve quality and effectiveness in public funded projects. This paper presents a study on the evaluation of competences of project team members of public funded projects in the public administration in Brazil. The research methodology employed document analysis and a survey with team members directly involved in programs and projects in Metropolitan Region of Manaus and in the Social and Environmental Program PROSAMIM. The conclusions indicate that, although project teams of public funded projects strive to achieve project goals, there are still several competence gaps in elementary project management practices. Future work will focus on the development of a competency model that aims to improve project success in the public sector.
\end{abstract}

Keywords: Project Management, Skills, Public Administration.

\section{Introduction}

Project management is a field that has been applied in organizations since ancient times, with the aim of getting the best results from projects through a more efficient and effective management. Project management practices in the public sector are quite recent, however, the increasing demand for quality and efficiency is driving further implementations in many public sector divisions [1].

The efficient management of project is benefiting organizations in the way it increases the probabilities of achieving their objectives, since it enables the control of many factors, such as costs, schedule and risks, thus favoring decision-making on the necessary actions that take projects in the right directions [2]. One of the greatest issues concerning the public sector is the achievement of organizational excellence. Literature suggests that there are great possibilities to develop changes in the mentality, behavior and in the rules towards achieving improvements in the public sector [3]. 
This paper presents an analysis on the competences of project team members in the public sector of Brazil, and their importance in the management of public projects and their results.

The objective of this research is to identify the project management competences that need to be nurtured in the public sector to improve project success, so the research question is: what project management competences need to be nurtured in public administration to improve project success?

The researchers, based on document analysis and a survey, identified individual competences deemed necessary for project managers that deal with specific circumstances of public funded projects. The results may contribute to the development of training programs that are more adapted to the needs of the public sector.

\section{$2 \quad$ Literature review}

Knowledge is one of the main pillars of modern society. Recent changes have made personal competences even more important in achieving professional success, in a global scenario where organizational competiveness is critical [4].

The main causes for project failure reported in the literature include: the lack of objectives definition from the early stages of projects, the complexity in team management, top management commitment, absence of planning and control, resistance to changes and inadequate communication [5].

Projects have been gaining increasing importance to organizations since they can contribute directly to the achievement of competitive advantages. As such, institutions have been promoting project management practices in increasingly professional manner. However, project success has not been the usual practice [6].

Public funded projects are required to deliver benefits to society that justify their investments. Stakeholders, particularly customers and subcontractors, are among the most interested in the implementation of project management practices [7].

The need to improve public administration in Brazil requires delivering public services with greater quality. The modernization of public administration is aimed at achieving its social purpose, thus driving improvements in its performance, transparency and battle against corruption and valuation of public services [8].

Organizations aim to attract people that are committed to their professional activities and that are able to aggregate value through their competences development. This is particularly noted in project oriented organizations due to their inherent nature that demands goals achievements [9].

The competences of project managers play a crucial role in delivering successful projects. These competences require specific personal, knowledge and skills traits in many areas, being the interpersonal, technical and cognitive aptitude among the most important competences [10].

ICB4 (Individual Competence Baseline 4) is a framework that describes three competences domains - People, Practice and Perspective - for project, programs and portfolio management. The "People" domain focuses on individuals' personal and social 
traits. The "Practice" domain portray technical aspects, and the "Perspective" domain refers to the contextual competences that must be mastered within and in a wider environment [11].

Qualified professionals will be increasingly more important, namely the skills that enable professionals to address dynamic and uncertain environments. Competence can be defined as the proper application of knowledge, skills and abilities towards the achievements of goals and results [11]. In that sense, individuals' competences play a critical role in the management of projects, programs and portfolios, and have the potential of realizing benefits not only to organizations but to society as a whole. The nurturing of individual competences requires constant learning in environments characterized by frequent changes, that in turn may have an effect on behavioral traits of an individual [12].

A project team typically includes staff from various disciplines, that embody knowledge and skills from several areas, working together to achieve projects goals [13]. The importance of a particular competence may vary from project to project, but their impact may be categorized in the following areas: project management success factors, stakeholders' management, goals and project requirements, risks and opportunities, quality, teamwork and communication, among others [11].

Projects should contribute to organizations' strategic plans. Therefore, a project manager must be capable of making decisions according to the organization strategy, demonstrating to top management that the project is aligned with the organization mission and to the execution of business strategies [11].

\section{Research methods}

This study was carried out in the Metropolitan Region of Manaus, composed of 13 municipalities. The Social and Environmental Program PROSAMIM was also studied, being a relevant program for this region, contributing to give relevance to the environmental, urban and social issues of the city. This program seeks to revitalize the Manaus creeks that present housing and environmental problems [14].

The research strategy used in this study was a survey, with a deductive approach, and as such can be categorized as an exploratory and descriptive type of research. The data collection was done through document analysis and a questionnaire. Data was collected in the area of infrastructure and basic sanitation. The participants were selected through non-probability sampling, using convenience sampling. The selection was done from people working directly with projects/programs in several public administration departments in the above mentioned region. Data collection began in August and was completed in September 2017. During the application of the questionnaires it was possible to have an initial idea of the current state in project management and to clarify the doubts that arose.

The questionnaire focused on the survey of project success factors and project management competences. The data was analyzed quantitatively, taking into account the answers obtained, allowing to draw some conclusions relevant to this research. 
Secondary data was collected through document analysis of the models previously used by government agencies and of project management literature available in books, scientific papers, internet, and documents provided by the entities involved in the Metropolitan Region of Manaus and PROSAMIM Program.

The questionnaire was divided into the following categories to facilitate data analysis:

1. Characterization of the respondent: the first part of the questionnaire includes information related to the profile of the respondent, namely: Gender; Age; Education; Current position in the organization; and Experience in the function.

2. Projects success factors: in the second part, it is questioned which percentage of projects was canceled before completion. Respondents are then asked to rank, by degree of importance, the factors they consider influencing project success, initiatives that could be taken to improve project management practices and critical factors that may influence projects failure.

3. Competences of project team members: the third part of the survey is intended to identify the skills that respondents feel most important for the performance of their work activities, where each respondent indicates if he or she uses the competence more or less frequently when managing their projects, according to a numerical scale of 1 to 5, where 1 means "No Knowledge/Experience" and 5 means "Great Knowledge/Experience".

In the questionnaire developed, the project management competences found in ICB4 are used: Perspective ( 5 elements), People (10 elements), Practice ( 14 elements), being a total of 29 competences. These questions helped to determine whether project management practices, with an emphasis on competences, are applied in the public sector.

\section{$4 \quad$ Results and discussion}

A research was carried out with project team members of Brazilian public organizations in the Metropolitan Region of Manaus and PROSAMIM program, with the objective of mapping the competences of public project team members, and to answer the research question proposed.

The organizations surveyed employ 250 people on average and have projects with different characteristics and team sizes, depending on their complexity and duration. The organizations analyzed confirmed informally that project management is very important for them and that they have the support of top management for its accomplishment. Data collection comprised a distribution of 52 questionnaires to people working on projects in the organizations mentioned above, of which 36 were valid and 16 were discarded because they were not complete.

With regards to the characterization of the respondents, it was observed that the sample has the following gender distribution: male (47\%) and female (53\%), with half of the respondents aged over 40 years, and the other half aged below 40 years. The most representative age range is from 41 to 45 years (22\% of the sample). The highest percentage of respondents have between 1 and 3 years of project management experience 
(36\%), but there is also a high percentage of people with more than 10 years of experience in the function $(33 \%)$. In the item referring to academic training, the respondents had high-school degree (8\%), bachelor degree (39\%) and master degree (53\%). None of the respondents have a $\mathrm{PhD}$ degree. In terms of areas occupied professionally, the areas were represented as: Functional manager (8\%); Project Manager (11\%); Team member $(31 \%)$; Other $(50 \%)$. This final value represents people with a role not defined in the questionnaire.

In order to gather information about the rate of successful projects, the percentage of projects canceled before completion was questioned, and only $14 \%$ of the respondents answered that no project was canceled. Cancel rates between 1\%-25\%, 26\%-50\%, $51 \%-75 \%$ and $76 \%-100 \%$ were reported by $42 \%, 22 \%, 8 \%$ and $14 \%$ of the participants, respectively. These values indicate that the success rate needs to be improved.

Regarding the factors that influence project success, the results are presented in Table 1. Respondents were asked to sort from 1 to 10 the 10 factors in table 1 , where 1 represents the most important and 10 the least important. For each factor a total score was calculated, multiplying by 10 the number of answers that placed it in 1st place, by 9 the number of answers that placed it in 2nd place, and so on. The total score was then normalized into a scale of 1 to 10 , but where 1 represents the least importance and 10 represents the most important, to be easier to relate the values.

Table 1. Factors influencing project success.

\begin{tabular}{lcc} 
Factors - Project Success & Total Score & Score (1.. 10) \\
\hline Data analysis & 232 & 9.85 \\
\hline Good communication & 220 & 8.97 \\
\hline Experienced project managers & 221 & 9.04 \\
\hline Monitoring and control & 171 & 5.35 \\
\hline Stakeholder participation & 112 & 1.00 \\
\hline Competent team & 234 & 10.00 \\
\hline Motivation of the project team & 181 & 6.09 \\
\hline Competence of the project managers & 210 & 8.23 \\
\hline Quality management & 189 & 6.68 \\
\hline Clear vision of objectives & 200 & 7.49 \\
\hline
\end{tabular}

Analyzing the results, it was verified that the factor considered most relevant for project success was "Competent team" (10 points), so it is recognized that the teamwork competences are very relevant to project success, as also mentioned by PMBOK Guide [15]. With more than 9 points, "Data analysis" appears, confirming the need of information to improve project management, and "Experienced project managers", also relate to competence issues. Next, there are two factors with more than 8 points: "Good communication" and "Competence of the project managers". Again, competences emerge as relevant. The other factors, although also relevant, were considered less relevant by the participants of this study.

Then, participants were asked to rank, by degree of importance, the 14 initiatives that should be taken to improve project management practices, where 1 represents the most important and 14 the least important. The calculations of the scores were done in the same way as explained in the previous case. The results are shown in Table 2. 
Table 2. Initiatives to improve project management practices.

\begin{tabular}{lcc} 
Initiatives - Improve PM practices & Total Score & Score (1 .. 10) \\
\hline Improve project planning & 376 & 10.00 \\
\hline Qualify the team & 359 & 9.44 \\
\hline Improve communication & 307 & 7.72 \\
\hline Improve conflict resolution & 328 & 8.41 \\
\hline Elaborate costs and deadlines with adequate forecasts & 348 & 9.07 \\
\hline Approve the project on time & 263 & 6.26 \\
\hline Improve human resources management & 240 & 5.50 \\
\hline Improve leadership & 263 & 6.26 \\
\hline Favor delivery on time & 206 & 4.38 \\
\hline Have appropriate material & 259 & 6.13 \\
\hline Anticipate requests made by customers & 201 & 4.21 \\
\hline Have an adequate preliminary study & 297 & 7.39 \\
\hline To promote the cultural values defined & 109 & 1.17 \\
\hline Improve and favor decision making & 104 & 1.00 \\
\hline
\end{tabular}

The initiative indicated as most relevant is "Improve project planning", followed by "Qualify the team" and "Elaborate costs and deadlines with adequate forecasts". It can be understood that planning and qualification are critical aspects of project management that need further improvement.

In order to complete this type of questions, participants were asked to sort the 8 critical factors that influence project failure, from 1 to 8 . The results obtained are shown in Table 3, with the calculations of the scores having been made as above.

Table 3. Critical factors that influence project failures.

\begin{tabular}{lcc} 
Critical factors - project failures & Total Score & Score (1 .. 10) \\
\hline Negative influence of the political will of stakeholders & 188 & 10.00 \\
\hline Inadequate organizational structure & 169 & 7.29 \\
\hline Incompetent team & 168 & 7.14 \\
\hline Project goal bad defined & 175 & 8.14 \\
\hline Lack of stakeholder involvement & 129 & 1.57 \\
\hline Lack of top management support & 125 & 1.00 \\
\hline Poor planning & 182 & 9.14 \\
\hline Lack of competence of the project manager & 162 & 6.29 \\
\hline
\end{tabular}

Respondents consider that the most critical factors that influence project failures are "Negative influence of the political will of stakeholders", "Poor planning", reinforcing previous results, and "Project goal bad defined". The last two factors may be related to the competence of those responsible for initial planning.

For a better understanding of the status of the participants in the study, in terms of their competences as defined by ICB4 (perspective, people and practice), the questions were divided into two parts, one including the degree of knowledge and another the experience. The scale used was 1 to 5 , with 1 meaning no knowledge/experience and 5 meaning a lot of knowledge/experience.

The results for perspective competences are presented in Table 4. 
Table 4. Knowledge and experience for perspective competences.

\begin{tabular}{lcc} 
Perspective competences & Knowledge (1..5) & Experience (1..5) \\
\hline Strategy & 2.20 & 4.43 \\
\hline Governance, structures and processes & 1.00 & 1.00 \\
\hline Compliance, standards and regulations & 1.00 & 1.00 \\
\hline Power and interest & 4.67 & 5.00 \\
\hline Culture and values & 5.00 & 2.14 \\
\hline
\end{tabular}

The competences that respondents seem to have more knowledge about are "Power and interest" and "Culture and values". In terms of experience, "Power and interest" remains, but "Strategy" is also ranked high. There seems to be more weaknesses in competences related to "Government, structures and processes" and "Compliance, standards and regulations", which may indicate the need for training in these areas.

The results for people competences are presented in Table $\mathbf{5}$.

Table 5. Knowledge and experience for people competences.

\begin{tabular}{lcc} 
People competences & Knowledge (1..5) & Experience (1..5) \\
\hline Self-reflection and self-management & 2.07 & 1.44 \\
\hline Personal integrity and reliability & 1.00 & 1.00 \\
\hline Personal communication & 4.47 & 3.89 \\
\hline Relations and engagement & 5.00 & 5.00 \\
\hline Leadership & 3.93 & 3.67 \\
\hline Teamwork & 4.73 & 3.67 \\
\hline Conflict and crisis & 1.27 & 2.78 \\
\hline Resourcefulness & 2.60 & 1.44 \\
\hline Negotiation & 1.80 & 1.67 \\
\hline Result orientation & 3.40 & 4.11 \\
\hline
\end{tabular}

The competence that respondents seem to have more knowledge and experience is "Relationships and engagement". Then "Teamwork" and "Personal communication". Still, with more than 3.5 points, "Leadership" emerges. All other competences have lower values of importance, except "Results orientation" that appears with high experience value (4.11), but less than 3.5 for knowledge.

Finally, the results for practice competences are presented in Table 6.

The competence that respondents seem to have more knowledge is "Project design", being "Organization and information" the one with higher experience value. "Plan and control" and "Risk and opportunity" also have values greater than 4 in both parts. Next "Change and transformation" and "Time" are also relatively well-quoted. Table 7 presents a summary of the results of this part of the study with the worst competences.

The "Governance, structures and processes" competence is related to the understanding of and the alignment with the established structures, systems and processes of the organization that provide support for projects and influence the way they are organized, implemented and managed. "Compliance, standards and regulations" describes how to interpret and balance the external and internal restrictions in a given area such as country, company or industry. These seem to be the perspective competences that most need to be improved. 
Table 6. Knowledge and experience for practice competences.

\begin{tabular}{lcc} 
Practice competences & Knowledge (1..5) & Experience (1..5) \\
\hline Project design & 5.00 & 2.80 \\
\hline Requirements and objectives & 2.56 & 1.00 \\
\hline Scope & 1.89 & 2.80 \\
\hline Time & 3.44 & 4.00 \\
\hline Organization and information & 3.89 & 5.00 \\
\hline Quality & 3.00 & 1.60 \\
\hline Finance & 1.00 & 1.00 \\
\hline Resources & 3.00 & 3.60 \\
\hline Procurement & 2.11 & 2.80 \\
\hline Plan and control & 4.11 & 4.00 \\
\hline Risk and opportunity & 4.11 & 4.40 \\
\hline Stakeholders & 3.44 & 3.40 \\
\hline Change and transformation & 3.67 & 4.20
\end{tabular}

Table 7. Summary of worst competences in the three areas.

\begin{tabular}{clll} 
Competence & Perspective & People & Practice \\
\hline Less Knowledge & $\begin{array}{l}\text { Governance, structures and processes / } \\
\text { Compliance, standards and regulations }\end{array}$ & $\begin{array}{l}\text { Personal integrity } \\
\text { and reliability }\end{array}$ \\
\hline Less Experience & $\begin{array}{l}\text { Governance, structures and processes / } \\
\text { Compliance, standards and regulations }\end{array}$ & $\begin{array}{l}\text { Personal integrity } \\
\text { and reliability }\end{array}$ & $\begin{array}{l}\text { Finance / Require- } \\
\text { ments and objectives }\end{array}$ \\
\hline
\end{tabular}

On the part of the people it was verified that the competence "Personal integrity and reliability" is pointed out as the weakest one in terms of knowledge and experience. Individuals must demonstrate personal integrity and reliability because a lack of these qualities may lead to a failure of the intended results. This also needs to be improved.

In the practice competences, respondents revealed to have less knowledge/experience of "Finance" and "Requirements and objectives". Finance includes all activities required for estimating, planning, gaining, spending and controlling financial resources. Requirements and objectives allows to establish the relationship between what stakeholders want to achieve and what the project is going to accomplish. These two practice competences also need to be improved.

\section{$5 \quad$ Conclusions and future research}

Public organizations face great challenges to respond to increasingly complex societal problems. Some have fragile structures due to insufficient resources, both financial and human, and knowledge weaknesses in general and also in the specific area of project management. The main objective of this study was to verify the positioning of the organizations that provide public services, namely municipalities, in relation to project management. It was carried out in the Metropolitan Region of Manaus, composed of 13 municipalities. The Social and Environmental Program PROSAMIM was also studied, being a relevant program for this region. This program seeks to revitalize the Manaus creeks that present housing and environmental problems [14]. 
Managing projects involves the need for multiple skills and this becomes a constant challenge for project managers who need to have knowledge and experience in many areas. The research was focused on answering the following research question: what project management competences need to be nurtured in public administration to improve project success?

The strategy used for the research was survey, using document analysis and a questionnaire to collect data. The questionnaire was distributed to 52 people working on projects of the entities mentioned above and 36 valid responses were received.

The questionnaire focused on the survey of project success factors and project management competences. The competencies analyzed where the 29 competencies proposed in ICB4. The data was analyzed quantitatively.

The results allowed to conclude that the success of managed projects can be improved, taking into account the rates reported. Only $14 \%$ of respondents reported that no project had been canceled.

Regarding the factors that influence the success of the projects, the most relevant factor was the competence of the team, so it is recognized that competences are very relevant in project success.

The opinion of respondents was also asked on the importance of initiatives that could be taken to improve project management practices. The results allow us to conclude that are several issues related to the qualification of the personnel involved in project management.

As for the critical factors that could most influence project failures, the results indicate lack of competence of those responsible for setting goals and planning.

Finally, the competences the respondents considered better knowing and having more experience on were collected, so as to try to define the gaps, based on the competences defined in ICB4, divided into the areas of Perspective, People and Practice.

A limitation of this paper is the reduced sample size. In future work, the questionnaire applied should be refined and applied to a large sample, from which the results obtained in this study will be complemented with, for example, semi-structured interviews with decision-makers in this area, to formulate a model of improvement actions aimed at increasing the success of public projects, not only in Brazil but also in other similar organizations in the World.

Acknowledgements. This work has been supported by FCT - Fundação para a Ciência e Tecnologia within the Project Scope: UID/CEC/00319/2019. 


\section{References}

1. Pestana, C.V.S., Valente, G.V.P.: Gerenciamento de projetos na administração pública: da implantação do escritório de projetos à gestão de portfólio na secretaria de estado de gestão e recursos humanos do Espírito Santo. In: III Congresso Consad de Gestão Pública. Consad, Brasília (2010).

2. Quadros, A.S., Carvalho, H.G.: O gerenciamento da comunicação de projetos públicos: como adaptar os processos do PMBOK/PMI à realidade da administração pública. Revista Brasileira de Planejamento e Desenvolvimento. 1, 52-60 (2012).

3. Amaral, H.K.D.: Desenvolvimento de competências de servidores na administração pública brasileira. Revista do Serviço Público Brasília. 57, 549-563 (2006).

4. Pant, I., Baroudi, B.: Project management education: the human skills imperative. International Journal of Project Management. 26, 124-128 (2008).

5. Young, T.L.: Successful Project Management. Kogan Page Publishers (2013).

6. Rabechini Jr, R., Pessoa, M.S.P.: Um modelo estruturado de competências e maturidade em gerenciamento de projetos. Revista Produção. 15, 34-43 (2005).

7. Forsythe, P.J.: In pursuit of value on large public projects using "spatially related valuemetrics" and "virtually integrated precinct information modeling." Procedia-Social and Behavioral Sciences. 119, 124-133 (2014).

8. Matias-Pereira, J.: Manual de gestão pública contemporânea. São Paulo: Atlas (2009).

9. Oliveira, R. De, Lopes, A., Sbragia, R., Linhares, E.: The psychological contract and project management as a core competence of the organization. Procedia - Social and Behavioral Sciences. 226, 148-155 (2016).

10. Vlahov, R.D., Mišić, S., Radujković, M.: The influence of cultural diversity on project management competence development-the Mediterranean experience. Procedia-Social and Behavioral Sciences. 226, 463-469 (2016).

11. IPMA: Individual Competence Baseline for Project, Programme \& Portfolio Management, International Project Management Association. (2015).

12. Tavares, E.S.: Uma contribuição para os processos da gerência de projetos através da gerência do conhecimento. Universidade de São Paulo (2004).

13. Liu, J.Y.C., Chen, H.H.G., Jiang, J.J., Klein, G.: Task completion competency and project management performance: The influence of control and user contribution. International Journal of Project Management. 28, 220-227 (2010).

14. Segundo, R.F.: Impactos do Programa PROSAMIM para os ribeirinho do Igarape do Quarenta na cidade de Manaus. Universidade Federal do Pará (2014).

15. PMI: A Guide to the Project Management Body of Knowledge (PMBOK GUIDE). Project Management Institute, Pennsylvania (2017). 